\title{
Review and Validity of Capital Asset Pricing Model: Evidence from
}

\section{Pakistan Stock Exchange}

\author{
Mengyun $\mathrm{Wu}^{1}$, Muhammad Imran ${ }^{1}$, Yanhua Feng ${ }^{1}$, Linrong Zhang ${ }^{1}$ \& Muhammad Abbas ${ }^{1}$ \\ ${ }^{1}$ School of Finance and Economics, Jiangsu University, Zhenjiang, China \\ Correspondence: Muhammad Imran, School of Finance and Economics, Jiangsu University, Zhenjiang, China. \\ Email: imran@ujs.edu.cn
}

Received: June 2, 2017

Accepted: December 6, 2017

Online Published: December 27, 2017

doi:10.20849/iref.v1i1.267

URL: https://doi.org/10.20849/iref.v1i1.267

This research is supported by China Postdoctoral Science Foundation funded project (2015M571708), Research and Practice Project of Teaching Reform of Graduate Education in Jiangsu Province (JGZZ1_056), Advanced Talent Project of Jiangsu University (09JDG050 \& 14JDG202) and Higher Education Commission of Pakistan (085-12336-Be5-152). JEL Classification: G12, G14, C52.

\begin{abstract}
Since the inception of prospects theory of Markowitz (1952) which leads to the development of CAPM has been studied and applied in many ways. Some researchers conclude that CAPM is valid and could be used for valuation of securities and cost of equity. However, critiques arise that CAPM is a single risk factor and remark that a single factor model cannot be generalized in the overall capital markets because the capital market absorbs many other risk factors. The CAPM has been applied to the Pakistan's Stock Exchange to check the validity of CAPM for a sample of 306 individual firms and 18 industrial portfolios. Two pass regression has been applied to check the applicability of CAPM in Pakistan's stock exchange. The results show that CAPM, single factor model is not valid for the technical analysis in Pakistan's capital market. The investors need to use other type of factor models which include other economic and non economic kind of variables for valuation of securities.
\end{abstract}

Keywords: CAPM, portfolios, Pakistan Stock Exchange, non financial, single factor model, two pass regression

\section{Introduction}

Investment in stock market has never been considered as free of risk. However, the securities associated with risk have been always compensated for higher rate of return than those of the risk free investment. The risk of securities can be minimized through efficient diversification, which means two or more than two securities are combined in such a way to form an efficient portfolio. However, as the number of securities increases in portfolio it's also caused increasing the efforts to compute the number of portfolio risks. The technique which gains momentum and popularity for use in computing the relationship between portfolio risk and return is called CAPM. Based on the above scenario CAPM can be defined as a model that express the relationship between risk and expected required rate of return; in CAPM a security expected required rate of return is the risk free rate of return plus an equity premium based on the systematic risk of the security.

Based on mean-variance theorem and on the behavior of risk-averse investors, there is an implied relationship between the market risk and the required expected return for each stock. In market equilibrium, a security is supposed to provide an expected return which is compatible with the systematic risk that stock prevails.

The more the systematic risk, the more the expected return from the security is. This relationship of the expected return and the market risk were proposed and explore by Sharp (1964) and named as CAPM as mentioned above. This model has important implications in the field of finance and economics ever its inception.

Markowitz's (1952a), the mean-variance (M-V) analysis and the contribution of Sharp (1964) and Linter's (1965), CAPM are the two such important pillars in asset pricing concept. CAPM is the foundation model on which many academic studies rely. Indeed, the recognition of these considerable contributions to the field of modern finance and economics. Chaira and Nathaphan (2014) applied and tested two models (Baysian Model Averaging and traditional CAPM regression) in Thailand stock market and concluded that BMA approach 
outperformed than the traditional regression model and had more predictability power.

The CAPM always remains under severe theoretical and empirical attacks. Studies of Scholes (1970), Hamada (1972), Galai and Masulis (1976) concluded that CAPM is valid and could be used for valuation of securities and cost of equity. The early criticism emerged from various empirical studies and concluded that CAPM is not very fit to empirical asset pricing, (Fama and French, 2004). However, the more severe criticism emerged from behavioral aspect of the mean-variance theory, on which CAPM rely. Nevertheless, despite many criticism CAPM is considered as one the best asset pricing technique for calculating the expected required rate of return and also could be used for cost of capital in capital budgeting decisions.

Like any other econometric model, the CAPM has also been considered as one the simple and precise model which touched the reality of the capital market. Nevertheless, it allows the investors and the policy makers to describe certain repercussions about this systematic risk and the size of the market risk premium necessary to compensate the investors for bearing that particular magnitude of risk. There are certain determinants of the CAPM which need to be discussed and used while examining the validity of the CAPM in certain capital markets.

\section{Objectives of the Study}

Capital Assets Pricing Model (CAPM) is the widely tested model for valuation of securities and the cost of equity and has been accepted (Lau \& quay, 1974). Hasan et al. (2013) examine and conclude that the "expected return-beta" relationship is linear in portfolios and unique risk has no effect on the expected return of portfolios. Köseoğlu and Mercangoz (2013) also conclude that the standard CAPM as well zero-beta CAPM are correspond to the expected returns of Istanbul Stock Exchange, Turkey. However, at the same time CAPM has been applied for the same purpose and rejected Eatzaz and Attiya (2008), Hanif (2009) due to its results which were not consistent with the actual returns of the capital market in Pakistan. Since CAPM inception Markowitz (1952) and Sharp (1964) it has occupied a primary place in the economics and financial literature and still part of the business text books in leading business schools across the world. We also understand that the CAPM has been tested in many research studies in Pakistan Javeed and Brooks (2007), Eatiza and Attiya (2008), Shah and Hacker (2013), Imran and Abbas (2013), Nida et al. (2015), and Zeshan (2016) among others. However, these studies consist of the data period as low as ranging from two years to eight years and firm sample size was ranging from three firms to 49 firms. Therefore, this research will contribute to the literature of having the maximum number of listed firm with maximum data that ever been so far in Pakistan. In addition to this the CAPM applicability for different sectors hasn't been explored.

The broad objective of this research is to review the capital asset price model and its components in relation to a particular capital market since its inception. Also to discuss different critiques in favor of CAPM and vice versa. Similarly, this study will also focus on whether the CAPM holds true in Pakistan's stock exchange? In addition to this, we would like:

To study whether the expected rate of return is linearly related with the risk associated with the stock, i.e., its systematic risk.

To study whether the systemic risk affects the industry portfolio returns.

To study that High risk, High return is true in Pakistan stock exchange or not?

The study conducted in Pakistan for testing CAPM were for very limited data period and were for limited number of companies which produce mixed results of acceptance and rejection of CAPM. In the current study the data period has been expanded to 14 years ranging from January 2001 to December 2014 covering at least 306 individual firms from 18 different non financial sectors listed in the Karachi stock exchange (KSE). Purpose of the research is to form a judgment about validity and authenticity of CAPM in Pakistan's capital market

The proceeding section of this paper will discuss the review of CAPM and its basic components followed by the critiques made by academic researchers and practitioners. In the last section the empirical analysis will be discussed related to the validity of CAPM in Pakistan's capital market.

\section{Significance of PSX}

Pakistan is among the emerging capital markets. The economy of country is the 24th biggest in the world in terms of "purchasing power", and 43th biggest in the world in terms of gross domestic product (GDP). Pakistan is the world's 6th-largest populated country, having youngest population with tenth largest work force in the word. The country has its nominal GDP per capita of $\$ 1,429$, which position it to 140 th in the world ranking. In 2014, foreign currency reserves of Pakistan exceeded $\$ 18.4$ billion (Note1) which has led to stable position on 
the long-term rating by Standard and Poor's (Note 2). In 2016, BMI Research (Note 3) report named Pakistan as one of the ten emerging economies. In October 2016, the International Monetary Fund (IMF) declare Pakistan as out of crises and the World Bank predict that the economic growth of Pakistan will reach to 5.4 percent due to the great inflow of foreign investment (Note 4).

The country has an International stock exchange called Pakistan Stock Exchange (PSX). KSE100 Index is the benchmark of the PSX to compare price over the period of time to determine the representative of higher market capitalization of the listed companies. At the end of year 2014, 654 companies of 34 sectors were listed in the Pakistan's stock exchange with a combined market capitalization of PKR. 7.33 trillion, i.e., US\$72 billion (Note 5). PSX has four indices namely, KSE100, KSE-All Share Index, KSE-20 and KMI-30. The most popular index tracking the overall prices on the market is the KSE-100 index of 100 stocks consisting of top market capitalization companies from each of the 34 sectors. KSE-100 Index achieved a high level of its age first time in the history when it reached at 15,737 points on April 20, 2008 with an increase of 7.4 per cent enabling this stock market as best among all the emerging markets (Note 6). After the global financial crises many equity markets bring back to its original trading positions. However, the Pakistan capital market turned around as one of the best stock market and the KSE100 index continuously followed the bullish trend and until August 2016 it reached to 39771 points. Historically, the Pakistan Stock Market (KSE100) reached an all-time high of 40058 by the end of August 2016 and having a previous record of the lowest index points of 538.89 in June of 1990. More recently on Thursday, January 26, 2017 Pakistan Stock Exchange (PSX) accomplished all time high index of 50,192 points and also reached Rs. 10 trillion of market capitalization (Note 7). Evidence is available for capital asset pricing model (CAPM) in KSE-Pakistan with first major study of Ahmad and Zaman (1999). They conclude that stock returns of KSE following cyclical trend. Ahmad and Qasim (2004) find positive relationship of positive news and stock return for KSE. Iqbal and Brooks (2007) report presence of non-linear risk-return relationship. Iqbal et al. (2010) compare CAPM and multifactor model and conclude that multifactor model is more convincing for Pakistan stock market. Similarly, Iqbal, et al. (2011) explore the interrelationship between international stock markets and showed the evidence of unidirectional causality running from New York stock exchange to Bombay and Karachi stock exchanges. PSX is an important emerging stock market and have uniqueness of high turnover and efficiency. This makes KSE a unique emerging capital market and best fit for the study. The equity premium of PSX as well as its firm level equity has not been explored nor the determinants of firm level equity premium. In this thesis the focus has been made on equity premium and its determinants.

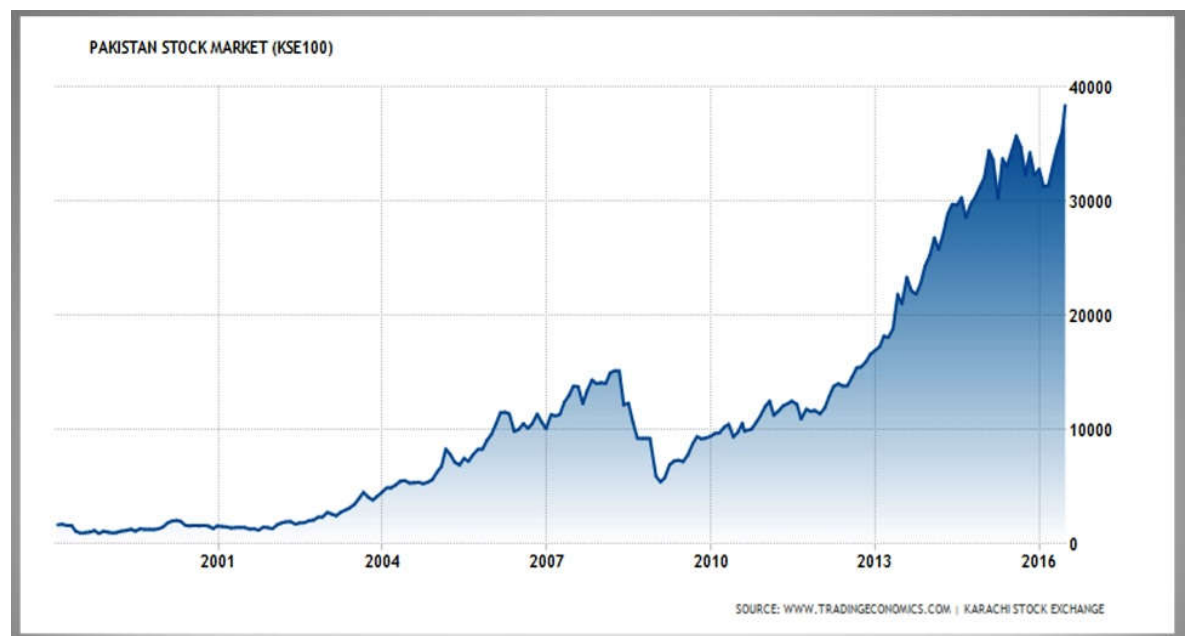

Figure 1. The performance of Pakistan Stock Exchange (KSE100 Index) from January 2000 to June 2016

Description: X-Axis represents the time period and Y-Axis represents the KSE100 Index.

Pakistan capital market, Karachi Stock Exchange (KSE) 100 index has been declared as one of the best emerging and best performing capital market due to its record breaking performance in 2013 and the same performance is still continued.

\section{The CAPM-Empirical and Tests}

In order to test the CAPM, the researchers employ different empirical testing techniques to check the validity of 
CAPM in different developing and developed markets. The CAPM has been rejected many times by different researcher based on ex post parameters. However, this model is valid all the time for using ex ante data in those markets. Just after the theoretical model of CAPM was developed and published, examining of this model was a fashion for the top researchers in the field of finance and economics. Out of these empirical studies, one have to believe that CAPM is empirically questionable, which results in decreasing its value and importance for industries and policy makers.

After reviewing of those critiques, in this research we claim that the empirical test and the results of the CAPM are inclusive: Although the CAPM could be rejected for ex-post parameters, but it cannot be rejected with ex ante parameters, specifically with ex ante beta. According to the definition of CAPM by Sharpe (1964) and Linter (1965) is tested as ex ante, rather than ex post parameters. So, based on the empirical results of ex ante, CAPM cannot be completely rejected and could be used for valuation and cost of capital.

The empirical tests of CAPM were carried out by first-pass and second-pass regressions and can be presented and used in the following manners.

$$
\begin{gathered}
\text { First-Pass: } \mathrm{R}_{\mathrm{it}}=\alpha_{\mathrm{i}}+\beta_{\mathrm{i}} \mathrm{R}_{\mathrm{mt}}+\mathrm{e}_{\mathrm{it}} \\
\text { Second-Pass: } \overline{\mathrm{R}}_{\mathrm{i}}=\gamma_{\mathrm{i}}+\gamma_{\mathrm{i}} \beta^{\prime}{ }_{\mathrm{i}}+\delta_{\mathrm{i}}
\end{gathered}
$$

Where: $R_{i t}$ and $R_{m t}$ represent the rate of return on the ith security and the market portfolio during period t, while $\beta_{i}$ is the estimate of the ith security risk as estimated in the first pass regression. The CAPM relates to the expected return of each stock $i$ and to its risk as describes below:

$$
\mu_{\mathrm{i}}=\mathrm{r}+\beta_{\mathrm{i}}\left(\mu_{\mathrm{m}}-\mathrm{r}\right)
$$

Where " $r$ " is the risk free rate of return and " $\mu_{\mathrm{m}}$ " is the return of the market portfolio. If the CAPM is valid, then we can expect that $\gamma_{0}$ will not be significantly different from the risk free interest rate and similarly, and $\mathrm{\gamma}_{1}$ will not be very different from $\mu_{\mathrm{m}}-\mathrm{r}$. Historically, the value of $\mathrm{R}^{2}$ is generally recorded as low as $4 \%$ to $5 \%$ for monthly data and could be recorded as up to $20 \%$ for annual data as long as the single security asset rather than portfolios of assets are considered as required by the CAPM (Levy, 1974). Mengyun et al. (2017) conclude that along with economic and financial factors, non-economic factors also cause volatility of stock return and equity premium. They consider terrorism and political instability in Pakistan as major non-economic factors of volatility in Pakistan stock market. However, there are still evidences of CAPM around the world and the authors will explore this phenomenon with firm and industry level.

\section{Testing of (CAPM) in Pakistan}

The following discussion has been made to test the validity of CAPM in Pakistan. This will allow us to find the equity risk premium of each security as well as for each industry. However, there are mixed discussions about the applicability of CAPM in different capital markets. Like any other econometric model, CAPM has also been based its certain assumptions.

\section{Research Methodology for Testing of CAPM}

The study uses monthly closing prices of 306 company stocks out of all listed at Karachi Stock Exchange for the period of January 2001 to December 2014 which fulfill the following criteria: Samples consist of stock from the non-financial sector. Only those stocks are included which have evidence of reasonable liquidity and stocks which have been traded for at least eight month during a year. A total 306 manufacturing companies from 18 manufacturing sectors were selected.

The data for the study has been collected from Pakistan Stock Exchange (PSE) official website, business recorder, economic survey of Pakistan and State Bank of Pakistan. Monthly stock prices of manufacturing firms have been collected for calculating the equity returns by using the following compound returns equation.

$$
\begin{aligned}
\text { Rit } & =\ln \left(\frac{\text { Pit }}{\text { Pit }-1}\right) \\
\text { Rmt } & =\ln \left(\frac{\text { Pmt }}{\text { Pmt }-1}\right)
\end{aligned}
$$

Where: Rmt and Rit are the compound continuous monthly returns for month, market and individual securities 
for time "t". Pmt and Pit are the current day closing prices, Pmt - 1 is the previous day closing prices, and ln stands for natural $\log$.

The methodology includes the beta $(\beta)$ computation through variance/covariance approach in order to calculate the required return; consequently price the underlying stocks. Pricing of the stocks and risk calculation is required by investors in portfolio composition. In this study the stock returns used are the capital gains only due to unavailability of information about the dividends paid for each period (monthly) of the study. Historical stock market returns are used for each firm and overall stock market portfolio of the KSE100 index for calculations of the results. The standard algebraic form of CAPM is as follows:

$$
E\left(R_{i}\right)=R_{f}+\beta_{i}\left(R_{m}-R_{f}\right)
$$

where: $E\left(R_{i}\right)=$ Expected return on capital asset "i”, $R_{f}=$ Risk free rate of interest; proxy usually used is return on treasury securities. $\mathrm{R}_{\mathrm{m}}$ = Return on market portfolio; proxy usually used is return on broad market index. $\beta_{\mathrm{i}}=$ Index of systematic risk. $\beta_{\mathrm{i}}$ is computed as covariance between asset " $r_{i}$ " return and market return " $\mathrm{r}_{\mathrm{m}}$ " divided by the variance of the market return.

\section{Calculation of Beta $(\beta)$ for Each Stock and Industry Portfolios}

$\beta$ is one of the major component in testing asset pricing models. The following formula could be used for the calculation of Beta Coefficient of a Stock.

$$
\begin{gathered}
\text { Beta }\left(\beta_{\text {im }}\right)=\frac{\sigma_{\mathrm{i}} \mathrm{r}_{\mathrm{im}}}{\sigma_{\mathrm{m}}} \\
\text { Beta }=\operatorname{Cov}\left(\mathrm{r}_{\mathrm{i}}, \mathrm{r}_{\mathrm{m}}\right) / \operatorname{Var}\left(\mathrm{r}_{\mathrm{m}}\right)
\end{gathered}
$$

Where: $r_{i}=$ Stock Return, $r_{m}=$ Market Return. The $\beta$ of the market portfolio is always equal to 1 . The $\beta$ of a security compares the volatility of its returns to the volatility of the market returns. Cases of ( $\beta$ ) Beta:

$\beta=1.0$ - the security has the same volatility as the market as a whole

$\beta>1.0$ - the security has more volatility than the market as a whole which increases the equity risk premium

$\beta<1.0$ - the security has less volatility than the market as a whole which decreases the equity risk premium

In CAPM, $E\left(R_{i}\right)$ is positively associated with $\mathrm{R}_{\mathrm{f}}, \mathrm{R}_{\mathrm{m}}$ and $\beta$.

First Pass and Second Pass Regressions: using data for 306 stocks of companies listed at PSE. The Lintner (1965) approach will be used to test CAPM. Following Fama and MacBeth (1973), first we estimate the following regression model to estimate the $\beta \mathrm{i}$ of each security in the sample using the basic steps. First, we run the time series regression for each individual stock to estimate the beta using the monthly prices data from January 2001 to December 2014. Second, we run the cross section regression using the beta and fitted values of step 1 regression in the following manners. First pass regression is estimated for calculating the average return, sensitivity of the market to individual security i.e., $\beta$.

$$
\operatorname{Re}=\beta_{0}+\beta_{1} \operatorname{KSERe}+\mu
$$

Where: Re is the monthly return of securities, and KSERe is the average monthly returns of the Karachi stock exchange (KSE), the leading Pakistan's capital market. 
Table 1. Estimated results of only 12 firms as sample of the total 306 firms

\begin{tabular}{lcccc}
\hline \multicolumn{1}{c}{ Company Name } & Alpha & Beta & Avg Return & RSQ \\
\hline Agriautos Industries & 0.02 & 1.29 & 0.27 & 0.75 \\
Atlas Battery Limited & 0.12 & 0.68 & 0.25 & 0.4 \\
Atlas Honda Limited & 0.11 & 0.56 & 0.21 & 0.29 \\
Baluchistan Wheels & 0.02 & 0.43 & 0.1 & 0.29 \\
Bela Automotive Ltd & -0.04 & 0.44 & 0.05 & 0.08 \\
Dewan Farooq Motors & 0.08 & 1.87 & 0.44 & 0.28 \\
Exide Pakistan Ltd & 0.11 & 0.87 & 0.28 & 0.58 \\
General Tyre \& Rub & -0.02 & 0.4 & 0.05 & 0.24 \\
Ghandara Nissan Ltd & 0.1 & -0.06 & 0.09 & 0.4 \\
Honda Atlas Cars PK & -0.18 & 1.33 & 0.09 & 0.68 \\
Indus Motor Co & 0.06 & 1.19 & 0.29 & 0.75 \\
Pak Suzuki Motor Co & -0.03 & 1.44 & 0.25 & 0.63 \\
\hline
\end{tabular}

The above Table 1 represents the first pass regression results of the individual firms. The total regression result table has been given the Appendix 1 of this research study for detail information. The results show that some of the firms have more risk which contradicts with the most popular assumptions of having high risk, high return. The $\mathrm{R}^{2}$ confirms that the returns are highly explained in the first pass regression but relation of risk and return is not supported the theory.

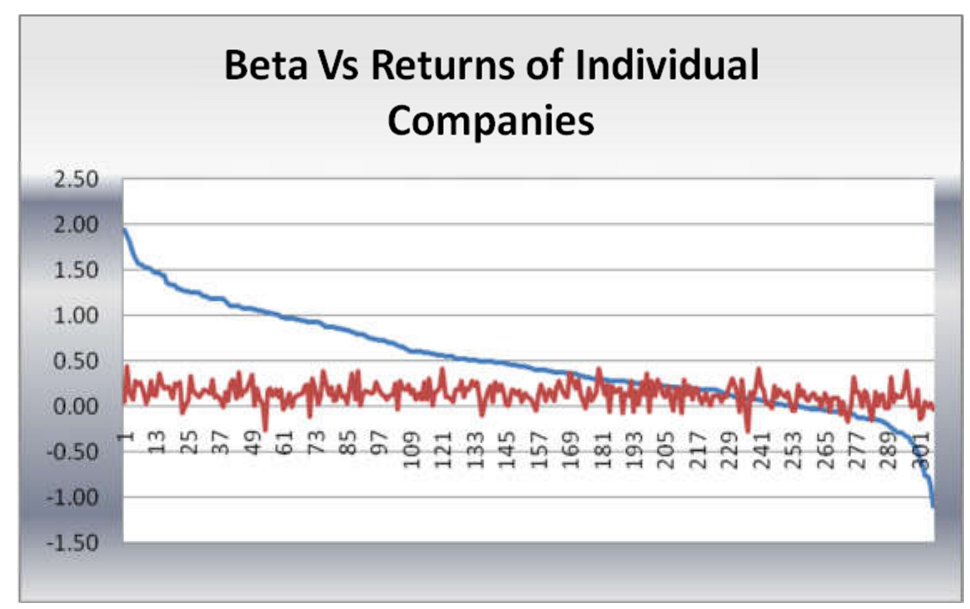

Figure 2. Risk, return graph of the total sample under study

The above graph confirms that given results are not reflecting conformity with high risk and high return. The security which posses high risk of 1.94 having return on 5\%. However, the security of having risk with zero has the return of $24 \%$. Similarly, other conditions are also not compatible with CAPM assumptions. Therefore, we cannot accept CAPM is suitable risk return model for Pakistani stock market. In the next step we need to run the second pass regression, estimated as follows:

$$
\operatorname{Re}=\beta_{0}+\beta_{1} \text { Beta }+\beta_{2} \text { Variance }+\mu
$$

where the variables are defined as before. The results of the second pass regression reported in the following table. 
Table 2. Two pass regression results of the firm returns

\begin{tabular}{ll}
\hline Intercept (The risk free rate) & 0.106 \\
\hline Beta/Slope (Systematic risk) & 0.053 \\
R-square & 0.057 \\
Average Return of Market (Rm) & 0.133 \\
Average Return of Risk Free (Rf) & 0.088 \\
(Rm-Rf) Equity Premium & 0.045 \\
\hline
\end{tabular}

Table 2 presents the estimated results of the second pass regression to check and confirm the validity of the CAPM on individual returns using monthly data for 14 years (January 2001 to December 2014). The intercept is positive i.e., 0.106 but not corresponds to the average risk free rate which is 0.088 , having the R-square value of 0.057 which is consistent with Levy (1978) and can confirm that the results of intercepts is correct. According to Levy (1978) the R-square value is always around 4 to $5 \%$ for monthly data and up to $20 \%$ for annual data. Similarly, the average return of the market is 0.133 and the value of Beta is 0.053 , in order to check that whether this value corresponds to the actual returns or not, the equity premium has been calculated which is 0.045 and is also not consistent with the actual returns of the market.

In order to study the Pakistan's capital market in detail, the proceeding discussion of this section will discuss the validity of CAPM by using industry portfolio returns. In order to analyze and estimate the results, we will be using the same Sharp-Linter (1965) approach, the two pass regression. The below table represents the results of the portfolio returns of the CAPM for the first pass regression.

Table 3. The first pass regression results of 18 manufacturing sectors of the portfolio return

\begin{tabular}{lcccc}
\hline Industry Portfolio & Alpha & Beta & Avg R & R-Sq \\
\hline Automobile and Parts & 0.01 & 0.19 & 0.16 & 0.54 \\
Chemicals & 0.07 & 0.07 & 0.12 & 0.09 \\
Electricity & 0.05 & 0.02 & 0.06 & 0.01 \\
Electronic \& Elect & 0.09 & 0.08 & 0.11 & 0.82 \\
Engineering & 0.19 & 0.57 & 0.18 & 0.61 \\
Fixed line Telecom & 0.28 & 0.17 & 0.09 & 0.77 \\
Food Producers & 0.13 & 0.03 & 0.14 & 0.33 \\
Household Goods & 0.07 & 0.04 & 0.09 & 0.07 \\
Industrial Metals & -0.13 & 0.2 & 0.12 & 0.3 \\
Multiutilities & -0.05 & 0.16 & 0.12 & 0.48 \\
Personal Goods & 0.1 & 0.07 & 0.12 & 0.06 \\
Pharma and Biotech & 0.22 & 0.64 & 0.19 & 0.05 \\
Tobacco & 0.19 & 0.51 & 0.32 & 0.1 \\
Travel and Leisure & 0.43 & 0.02 & 0.16 & 0.93 \\
\hline
\end{tabular}

Table 3 explains that first pass regression of the portfolio returns, which shows that the monthly average returns of different portfolios are ranging from 9 percent to 32 percents with R-Square ranging from 5 percent to 93 percents. Similarly, the risk measure Beta is ranging from 0.02 to 0.64 . 


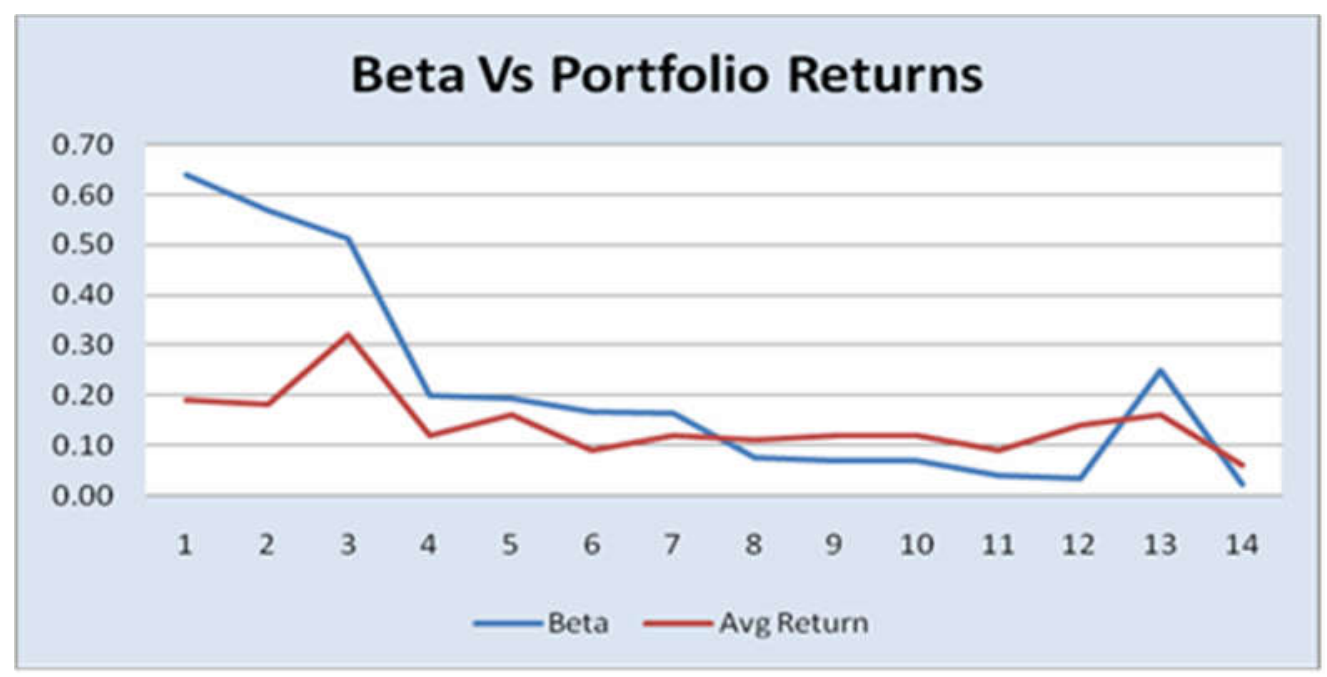

Figure 3. Beta vs. industrial portfolio returns for 2001 to 2014

The Figure 3 explains that the results of the industrial portfolio are not consistent as required for the validity of CAPM. The higher risk does not correspond to higher returns. Only in few instances the returns are following the risk pattern which is also not as expected.

Table 4. Second Pass Regression

\begin{tabular}{ll}
\hline Intercept (Risk free Rate) & 0.0931 \\
\hline Beta (Risk Index) & 0.2252 \\
R-square & 0.5609 \\
$\mathrm{Rm}-\mathrm{Rf}$ (Industry Premium) & 0.0534 \\
$\mathrm{Re}=\mathrm{Rf}+\mathrm{B}$ (Rm - Rf) & 0.1051 \\
Average Portfolio Return & 0.1414 \\
Average Risk Free Rate & 0.0880 \\
\hline
\end{tabular}

Table 4 explains the estimated results of the second pass regression which indicates that the intercept is positive 0.093 and consistent with risk free rate of 0.088 with slightly difference. This could confirm that with respect to the intercept, the CAPM is valid for industrial portfolio. However, the calculated value of expected return is 0.1051 and the actual return of the industrial portfolio is 0.1414 which does not correspond to the CAPM validity. The R-square value of 0.5609 of the 2 nd pass regression of the non financial industrial portfolio explains that the results more accurately predicted and consistent with Levy (1978) to reject the CAPM for valuation of securities in context of Pakistan's capital market.

\section{Conclusion}

Investment in stock market has never been considered as free of risk. However, the securities associated with risk have always been compensated for higher rate of return than those of the risk free investment. As the famous assumption that "high risk yield higher return", the risk of securities can be minimized through efficient diversification, means two or more than two securities are combined in such a way with the help of security market line (SML) to form an efficient portfolio. However, as the number of securities increases in portfolio it's also caused increasing the efforts to compute the number of portfolio risks. The technique which gains momentum and popularity for use in computing the relationship between portfolio risk and return is called CAPM. Based on the above scenario CAPM can be defined as a model that expresses the relationship between risk and expected required rate of return; in CAPM a security expected required rate of return is the risk free rate of return plus an equity premium based on the systematic risk of the security.

In this research study, the researchers have provide a review of the CAPM developed by Markowitz (1952), 
Tobin (1958) and the work was further extended by Sharp (1964) and Linter (1965). CAPM, based upon Markowitz's Mean-Variance (MV) Approach (1952) and Tobin (1958) Funds Separation approach with the assumptions of market equilibrium, high risk yield high returns as portrayed by Capital Market Line (CML). These were the classical but the very important development in CAPM and Sharpe eventually won noble prize in 1990 for his work on CAPM.

During the review of CAPM since its inception, this has been found that just after the introduction of CAPM as a new technique for asset pricing in the capital market. Many academician and researchers started to check the validity of CAPM through real market data. Beta as the single factor of risk was not accepted to many researcher and was not agree with it. Roll and Rose (1976) present the arbitrage pricing theory (APT) in which they combine the risk of other factors to be computed. Roll (1977) and Rose (1977) critique that beta as the only measure of risk is not enough to generalize the risk of the total market and rejected the CAPM. Price-Earnings ratio, Book-to-Market ratio, Size-effect and momentum could be considered as the risk factor for valuation of securities in the capital market Basu (1977), Fama and French (1993, 1996).

Similarly, the ex post and en ante also been consider an issue in the applicability of CAPM. After reviewing of those critiques, in this research it has been claimed that the empirical test and the results of the CAPM are inclusive: Although the CAPM could be rejected for ex-post parameters, but it cannot be rejected with ex ante parameters, specifically with ex ante beta. According to the definition of CAPM by Sharpe (1964) and Linter (1965) is tested as ex ante, rather than ex post parameters. So, based on the empirical results of ex ante, CAPM cannot be completely rejected and could be used for valuation and cost of capital.

In second part of this research, the researcher has examined to check the validity of CAPM in Pakistan's stock exchange (PSX). The data for 306 non-financial firms have been collected from eighteen non financial sectors covering the period of January 2001 to December 2015. Two pass regression analysis has been used to check the validity of CAPM on the individual firms returns. In the first pass regression, we have calculated the 306 firms Intercept, Betas, Average Returns and R-squares, which conclude that the assumption of higher risk, higher returns in not fulfilled. The securities with high risk do not yield high return. Also, the intercept value is not corresponding with the risk free rate. In the 2 nd pass regression, the similar results have been found that the calculated expected return is not corresponding with the actual returns of securities. This has been concluded that CAPM is not valid in the context of Pakistan's stock exchange data and the results are consistent with Eitizaz and Attiya (2008) and Nyaganra. et al. (2016). However, the results of CAPM are close enough to the actual returns of stock market. The same process has been revised for industry portfolios data and the results revealed that only intercept is correspond to the risk free rate of return. The results of CAPM are not consistent with the actual portfolio. This has been concluded that CAPM is not valid for valuation of securities in PSX. The investors need to use other technical methodologies for valuation of securities before investment in stock market in Pakistan.

\section{Acknowledgement}

The author is thankful to the editor and the valuable comments from anonymous reviewers of the International Research in Economics and Finance. Also the author would like to thank the participants and discussant of 6th SINO business forum held in Jiangsu University, Zhenjiang, People's Republic of China.

\section{References}

Abbas, Q., Ayub, U., \& Kashif, S. (2011, April). CAPM-Exclusive Problems Exclusively Dealt. Interdisciplinary Journal of Contemporary Research in Business.

Basu, \& Sanjoy. (1977). Investment Performance of Common Stocks in Relation to their Price Earnings Ratios: A Test of the Efficient Market Hypothesis. Journal of Finance, 32. https://doi.org/10.1111/j.1540-6261.1977.tb01979.x

Basu, S. (1997). The conservatism principle and the asymmetric timeliness of earnings. Journal of Accounting \& Economics, 24(1), 3. https://doi.org/10.1016/S0165-4101(97)00014-1

Bellelah et al. (2016). Does the equity premium puzzle persist during financial crisis? The case of the French equity market. Research in International Business and Finance, 39(1), 851-866.

Black, F. (1993). Beta and return. Journal of Portfolio Management, 20, 8-18. https://doi.org/10.3905/jpm.1993.409462

Black, F., \& R. Litterman. (1992). Global Portfolio Optimization. Financial Analysts' Journal, 48(5), 28-43. https://doi.org/10.2469/faj.v48.n5.28 
Chairakwattana, K., \& Nathaphan, S. (2014). Stock Return Predictability by Bayesian Model Averaging: Evidence from Stock Exchange of Thailand. International Journal of Economic Sciences, 3(1), 47-63.

Chan, K. C., \& Chen, N. (1988, June). An Unconditional Asset-Pricing Test and the Role of Firm Size as an Instrumental Variable for Risk. The Journal of Finance, XLIII(2).

Eatzaz, \& Attiya. (2008). Testing Multifactor Capital Asset Pricing Model in Case of Pakistani Market. International Research Journal of Finance and Economics, 25, 114-138.

Elif Akben-Selcuk. (2016). Does Firm Age Affect Profitability? Evidence from Turkey. International Journal of Economic Sciences, V(3), 1-9. https://doi.org/10.20472/ES.2016.5.3.001

Fama, E. F., \& French, K. R. (1993). The cross-section of expected stock returns. Journal of Finance, 47, 427-465. https://doi.org/10.1111/j.1540-6261.1992.tb04398.x

Fama, E. F., \& French, K. R. (1996). Size and book-to-market factors in earnings and returns. Journal of Finance, 50, 131-156. https://doi.org/10.1111/j.1540-6261.1995.tb05169.x

Fama, E. F., \& J. D. Macbeth. (1973). Risk, Return, and Equilibrium: Empirical Tests. Journal of Political Economy, 81(3), 607. https://doi.org/10.1086/260061

Fama, Eugene F., \& Kenneth R. French. (2004). The Capital Asset Pricing Model: Theory and Evidence. Journal of Economic Perspectives, 18(3), 25-46. https://doi.org/10.1257/0895330042162430

Hanif, Muhammad. (2010). Testing Application of CAP Model on KSE-Pakistan: A Case Study on Tobacco Sector Management Accountant March 2010 Issue. Retrieved from http://ssrn.com/abstract=1494906

Hasan, et al. (2013). Analyzing and estimating portfolio performance on the Bangladesh stock market. American Journal of Applied Sciences, 10(2), 139-146. https://doi.org/10.3844/ajassp.2013.139.146

Imran, \& Abbas. (2013). The relationship between macroeconomic variables and cement industry returns: Empirical Evidence from Pakistani Cement Industry. International Journal of Research in Commerce, IT \& Management Volume, 3(3), 10-17.

Köseoğlu, \& Mercangoz. (2013). Testing the validity of standard and zero beta capital asset pricing model in Istanbul stock exchange. International Journal of Business, Humanities and Technology, 3(7), 58-67.

Lau, \& Quay. (1974). The Tokyo stock exchange and the capital asset pricing model. The journal of finance, 29(2), 507-514. https://doi.org/10.1111/j.1540-6261.1974.tb03063.x

Levy, R. A. (1974). Beta coefficients as predictors of returns. Financial Analysts Journal, 30, 61-66. https://doi.org/10.2469/faj.v30.n1.61

Lintner, J. (1965). The Valuation of Risk Assets and the Selection of Risky Investments in Stock Portfolios and Capital Budgets. Review of Economics \& Statistics, 47(1), 13. https://doi.org/10.2307/1924119

Markowitz, H. M. (1952, March), Portfolio Selection. Journal of Finance, 77-91.

Markowitz, H. M. (1959). Portfolio Selection: Efficient Diversification of Investments. New York: John Wiley \& Sons.

Markowitz, H. M. (1991). Foundations of Portfolio Theory. J. Finance, 46(2), 469-477. https://doi.org/10.1111/j.1540-6261.1991.tb02669.x

Mehra, R., \& E. C. Prescott. (1985). The Equity Premium. Journal of Monetary Economics, 15(2), 145-161. https://doi.org/10.1016/0304-3932(85)90061-3

Mengyun et al. (2017). Impact of Terrorism and Political Instability on Equity Premium: Evidence from Pakistan. Physica A, 492, 1753-1762. https://doi.org/10.1016/j.physa.2017.11.095

Mossin, J. (1966). Equilibrium in a Capital Asset Market. Econometrica, 34(4), 768-783. https://doi.org/10.2307/1910098

Nyaganra. et al. (2016). An Empirical Test of the Validity of the Capital Asset Pricing Model on the Zimbabwe Stock Exchange. International Journal of Economics and Financial Issues, 6(2), 365-379.

Roll, R. (1977). Critique of Asset Pricing Theory Test: Past and Potential Testability of Theory. Journal of Financial Economics, 4(2), 129-176. https://doi.org/10.1016/0304-405X(77)90009-5

Rosenberg, B., Reid, K., \& Lanstein, R. (1985). Persuasive evidence of market inefficiency. Journal of Portfolio Management, 11, 9-17. https://doi.org/10.3905/jpm.1985.409007 
Ross, S. A. (1976). The arbitrage theory of capital asset pricing. Journal of Economic Theory, 13, 341-360. https://doi.org/10.1016/0022-0531(76)90046-6

Roy, A. D. (1952). Safety-First and the Holdings of Assets. Econornetrica, 20, 431-449. https://doi.org/10.2307/1907413

Sharpe, W. F. (1964). Capital Asset Prices: A Theory of Market Equilibrium under Conditions of Risk. Journal of Finance, 19(3), 425.

Tobin, J. (1958). Liquidity preference as behavior towards risk. Review of Economic Studies, 26, 65-86. https://doi.org/10.2307/2296205

Treynor, J. (1962). Toward a Theory of Market Value of Risky Assets (Unpublished manuscript).

\section{Notes}

Note1. www.sbp.gov.pk

Note 2. Foreign currency reserves cross $\$ 10 \mathrm{~b}$ mark. The Express Tribune.

Note 3. World Economic Forum. Retrieved 2016-07-31.

Note 4. China-Pakistan Economic Corridor (CPEC).

Note 5. www.kse.gov.pk

Note 6. www.kse.com.pk

Note 7. www.kse.gov.pk

\section{Copyrights}

Copyright for this article is retained by the author(s), with first publication rights granted to the journal.

This is an open-access article distributed under the terms and conditions of the Creative Commons Attribution license (http://creativecommons.org/licenses/by/4.0/). 